Review Article

\title{
A Potential Linking between Vitamin $D$ and Adipose Metabolic Disorders
}

\author{
Zhiguo Miao $\mathbb{D}$, ${ }^{1}$ Shan Wang $\mathbb{D}^{1},{ }^{1}$ Yimin Wang, ${ }^{1}$ Liping Guo $\mathbb{D},{ }^{1}$ Jinzhou Zhang $\mathbb{D}{ }^{1}$ \\ Yang Liu $\mathbb{D},{ }^{1}$ and Qiyuan Yang $\mathbb{D}^{2}$ \\ ${ }^{1}$ College of Animal Science and Veterinary Medicine, Henan Institute of Science and Technology, Xinxiang, Henan 453003, China \\ ${ }^{2}$ Department of Molecular, Cell and Cancer Biology, University of Massachusetts Medical School, Worcester, MA 01605, USA \\ Correspondence should be addressed to Shan Wang; sirui610@126.com and Qiyuan Yang; yqiyuan@gmail.com
}

Received 20 August 2019; Revised 10 November 2019; Accepted 27 November 2019; Published 19 February 2020

Guest Editor: Roberto Martínez-Beamonte

Copyright (C) 2020 Zhiguo Miao et al. This is an open access article distributed under the Creative Commons Attribution License, which permits unrestricted use, distribution, and reproduction in any medium, provided the original work is properly cited.

\begin{abstract}
Vitamin D has been discovered centuries ago, and current studies have focused on the biological effects of vitamin D on adipogenesis. Besides its role in calcium homeostasis and energy metabolism, vitamin D is also involved in the regulation of development and process of metabolic disorders. Adipose tissue is a major storage depot of vitamin $\mathrm{D}$. This review summarized studies on the relationship between vitamin $\mathrm{D}$ and adipogenesis and furthermore focuses on adipose metabolic disorders. We reviewed the biological roles and functionalities of vitamin $\mathrm{D}$, the correlation between vitamin $\mathrm{D}$ and adipose tissue, the effect of vitamin D on adipogenesis, and adipose metabolic diseases. Vitamin D is associated with adipogenesis, and vitamin D supplements can reduce the burden caused by metabolic diseases. The review provides new insights and basis for medical therapy on adipose metabolic diseases.
\end{abstract}

\section{Introduction}

Vitamin D is an essential nutrient for the prevention of rickets and is responsible for the intestinal absorption of calcium, phosphate, and magnesium $[1,2]$. Vitamin D can be obtained from food, but most of it is synthesized from 7 dehydrocholesterol in the skin via ultraviolet irradiation $[3,4]$. The mechanism of vitamin $\mathrm{D}$ action is through its active form, $1 \alpha, 25$-dihydroxyvitamin $\mathrm{D}_{3}\left[1 \alpha, 25(\mathrm{OH})_{2} \mathrm{D}_{3}\right]$, which regulates the transcription of target genes and thus plays an important role in calcium homeostasis and metabolism [5-7]. Vitamin D deficiency or insufficiency is still a common issue in developing countries $[8,9]$. Among 734 adolescents ranging from 12 to 18 years, $87.6 \%$ of participants had vitamin D deficiency [10]. Aside from its involvement in calcium and bone mineralization, vitamin $\mathrm{D}$ has multiple functions in adipose tissue, adipogenesis, glucose-insulin homeostasis, cell growth, and so on [11-13].

Adipose tissue is a vital organ in energy homeostasis and glucose metabolism [14-16]. Adipose tissue is also an endocrine organ secreting proteins and releasing fatty acids
$[17,18]$. It is composed of various cell types, including mature adipocytes, preadipocytes, fibroblasts, macrophages, and immune cells. The predominant cell types existing in adipose tissue are mature adipocytes. Preadipocytes differentiate into mature adipocytes in adipose tissue, and this process requires the regulation of transcription factors (peroxisome proliferator-activated receptor (PPAR), CCAAT enhancer-binding protein (C/EBP), and Kruppellike factor proteins) $[19,20]$. Vitamin $D$ is mainly stored in adipose tissue, while vitamin D receptor (VDR) is expressed in adipose tissue [21, 22]. VDR is an activated transcription factor of active vitamin D. Previous studies investigated the effect of vitamin D on adipogenesis in animal models $[23,24]$, and results suggested that vitamin $\mathrm{D}$ exerts antiadipogenic activity in 3T3-L1 preadipocytes [25-27]. Meanwhile, vitamin D deficiency or insufficiency is involved in the regulation of insulin secretion, glucose levels, and inflammation causing adipose metabolic diseases, such as obesity, multiple sclerosis, diabetes, and fatty liver [28-32].

Hence, we reviewed the correlation between vitamin D and adipose tissue, along with related metabolic disorders 


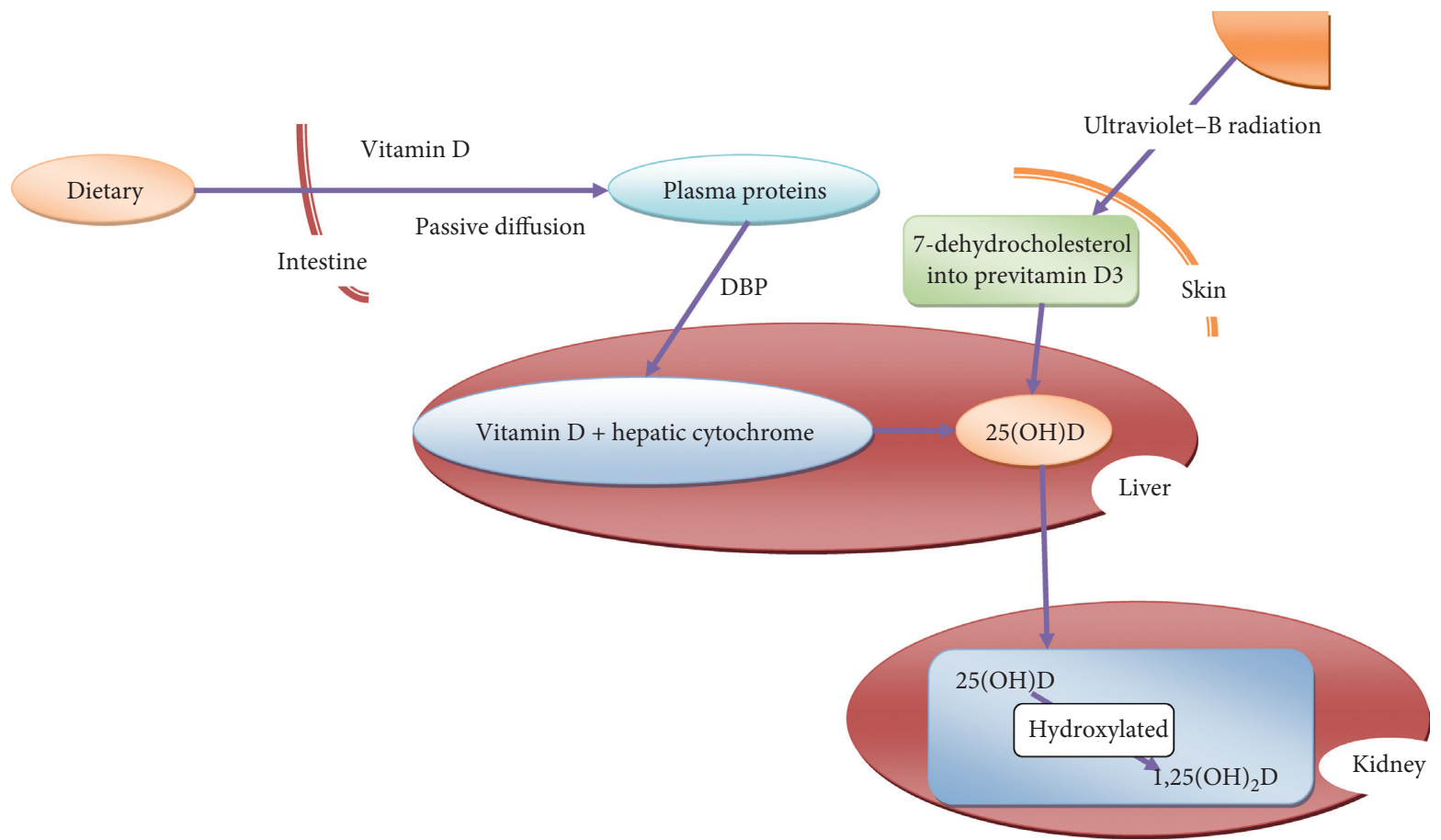

FIGURE 1: Bioactivation of vitamin D.

(diabetes, nonalcohol fatty liver, and cardiovascular diseases). This study aimed to establish the relationship between vitamin $\mathrm{D}$ and metabolic disorders and furthermore to determine whether such disorders are affected by vitamin $\mathrm{D}$ supplementation, adipose vitamin $\mathrm{D}$ metabolism, and increased or reduced vitamin $\mathrm{D}$ activation. The vitamin $\mathrm{D}$ status, regulation of vitamin $\mathrm{D}$ by adipose tissue, effect of vitamin $\mathrm{D}$ on adipogenesis, and related metabolic diseases were also discussed.

\section{Bioactivation of Vitamin D}

Only a small amount of fat-soluble vitamin $\mathrm{D}$ can be obtained from the diet and from supplements [33]. The major source of vitamin $\mathrm{D}$ is produced in the skin through a sunlight-dependent chemical reaction $[4,34]$. Exposure of the skin to ultraviolet- $\mathrm{B}$ radiation from the sun converts 7 dehydrocholesterol into previtamin $\mathrm{D}_{3}$, which can be isomerized to vitamin $D_{3}$ [35]. Vitamin $D_{3}$ is then converted into calcifediol $(25-(\mathrm{OH}) \mathrm{D})$ in the liver and further hydroxylated into $1,25(\mathrm{OH})_{2} \mathrm{D}$ in the kidney (Figure 1) [36]. Normally, the serum concentration of $25-(\mathrm{OH}) \mathrm{D}$ is measured to determine an individual's vitamin $\mathrm{D}$ status in serum, whereas $1,25(\mathrm{OH})_{2} \mathrm{D}$ is the biological active form of vitamin D [37-39].

The biological activity of $1,25(\mathrm{OH})_{2} \mathrm{D}$ is mediated through binding to VDR [40]. VDR is also well-documented as calcitriol receptor and is a member of the steroid hormone nuclear receptor family [41]. In humans, VDR is encoded by the VDR gene [42]. VDR widely exists in tissues and cells, such as skeleton, kidney, renal, skin, and immunocytes [4]. In nuclear, $1 \alpha, 25-(\mathrm{OH})_{2} \mathrm{D}_{3}$, which is the active form of vitamin $\mathrm{D}$, is capable of binding to VDR and form a heterodimer with retinoid $\mathrm{X}$ receptor ( $\mathrm{RXR}$ ); the complex binds to RNA polymerase and VDR interacting protein, resulting in the regulation of DNA transcription $[43,44]$. Downstream targets of VDR are involved in calcium homeostasis, immune response, and cancer development [45]. Hindered VDR expression can impact diverse diseases, including cardiovascular disease, diabetes, tumors, tuberculosis, and multiple sclerosis [46].

After dietary intake, vitamin $\mathrm{D}$ needs to be absorbed by meal of fat through passive diffusion in the intestine. The absorbed vitamin $\mathrm{D}$ is transported to the liver by binding to diverse plasma proteins, such as vitamin D-binding protein (DBP), $\beta$-lipoprotein, and albumin [47-49]. DBP is an important carrier protein that can attenuate the toxicity of vitamin $\mathrm{D}$ by limiting its bound metabolites to target cells [50]. In the liver, vitamin $\mathrm{D}$ is converted into $25(\mathrm{OH}) \mathrm{D}$ catalyzed by the several hepatic cytochrome P-450s [51-53]. Of note, the metabolite is released into plasma and transported to the kidney, where it is converted into $1,25(\mathrm{OH}) \mathrm{D}$, and is finally transported throughout the body (Figure 1) [54]. After synthesis, absorption, and transport, active vitamin D is distributed to hydrophobic parts of tissues [55]. Unlike other fat-soluble vitamin, vitamin $\mathrm{D}$ is not stored in the liver (except in some fish livers) [56]. Vitamin D is mostly stored in adipose tissue, and a large amount of vitamin $\mathrm{D}$ is combined with lipid, resulting in release and metabolic difficulties $[57,58]$.

\section{Vitamin D and Lipid Metabolism}

3.1. Regulation of Activation of Vitamin D by Adipose Tissue. Aside from the important roles of vitamin $\mathrm{D}$ in intestinal calcium, phosphate uptake, and bone mass regulation, it is 


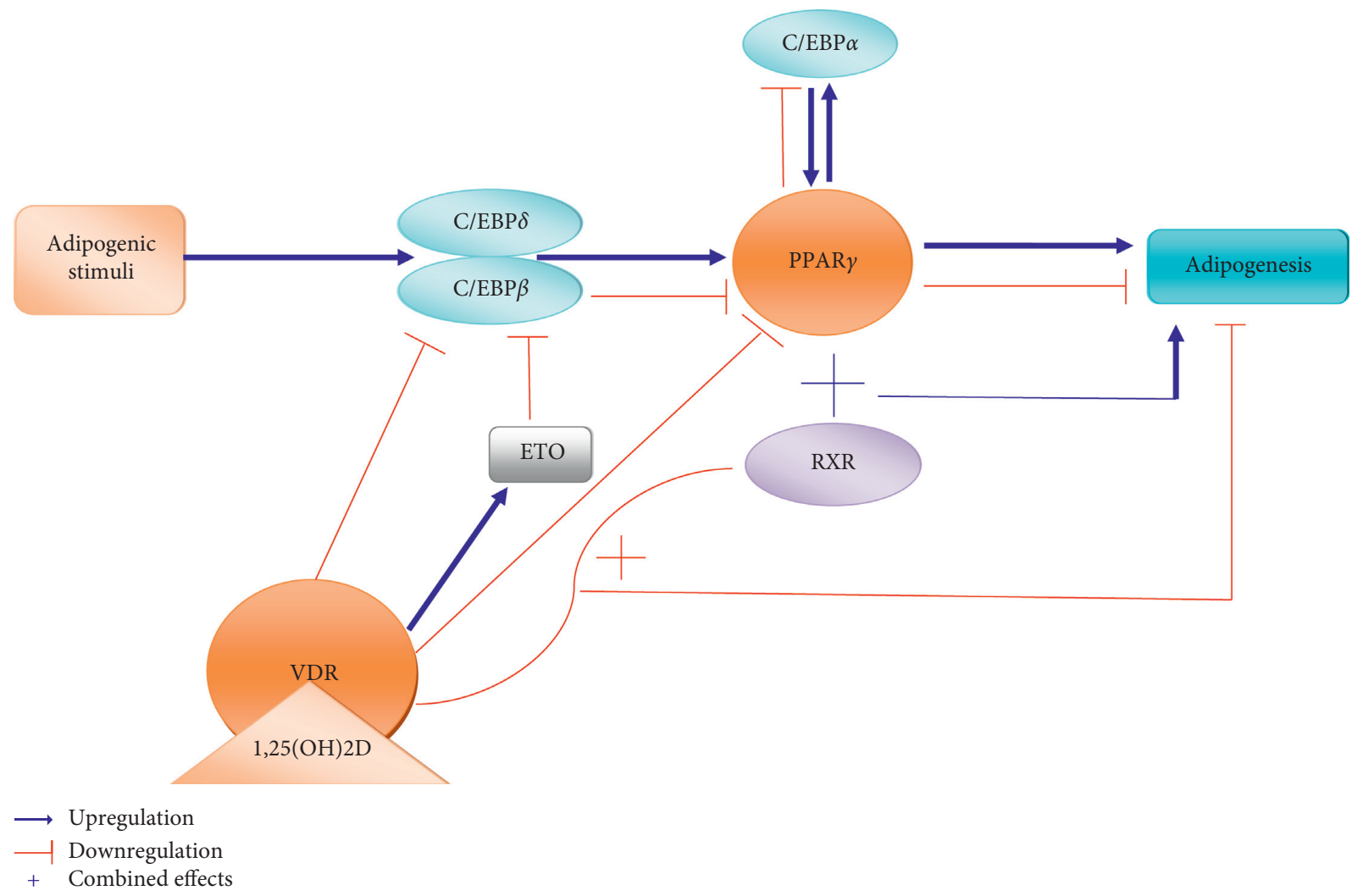

FIGURE 2: The relationship between vitamin D and adipogenesis. ETO: eight twenty-one. PPAR $\gamma$ : peroxisome proliferator-activated receptor $\gamma$. $\mathrm{C} / \mathrm{EBP} \alpha$ : CCAAT enhancer binding protein $\alpha . \mathrm{C} / \mathrm{EBP} \beta$ : CCAAT enhancer binding protein $\beta$. C/EBP $\delta$ : CCAAT enhancer binding protein $\delta$. VDR: vitamin D receptor. RXR: retinoid X receptor.

also involved in other processes, including cell growth, immune functions, inflammation regulation, and neuromuscular functions [59-63]. Vitamin D could be regulated by hydroxylation that includes two-step enzymatic processes. Hydroxylation is performed by enzymes CYP27B1, CYP2J2, CYP27A1, and CYP3A4 in the liver and CYP27B1 in the kidney [64]. These enzymes are consecutively expressed in subcutaneous adipose tissue (SAT) and visceral adipose tissue $[65,66]$. The CYP27B1 gene is expressed in the SAT of lean individuals and in 3T3-L1 preadipocytes, and it is regulated by calcitonin, hormones, calcium, and phosphorus [53]. Thus, the location of these enzymes in adipose tissue could implicate the production of active vitamin D.

Previous reports showed that the concentrations of vitamin $\mathrm{D}$ in blood below $50 \mathrm{nmol} / \mathrm{L}$ indicated vitamin $\mathrm{D}$ deficiency, and the reference values of vitamin $\mathrm{D}$ levels in blood should exceed $75 \mathrm{nmol} / \mathrm{L}$; lower serum vitamin $\mathrm{D}$ levels correlated with higher frequency of obesity and excessive body weight [67-69]. Circulating 25(OH)D level depends on the storage of vitamin $\mathrm{D}$ in adipose tissue, indicating that adipose tissue probably affects the activation, regulation, or action of obesity via regulation of vitamin $\mathrm{D}$ $[57,70,71]$. In the presence of calcitriol, adipogenesis is blocked by VDR via downregulating both $\mathrm{C} / \mathrm{EBP} \beta$ nuclear protein levels and mRNA expression. In addition, 1,25(OH) 2D3 allows for the upregulation of eight twenty-one (ETO), which is the core-repressor of $\mathrm{C} / \mathrm{EBP} \beta$, and finally leads to $\mathrm{C} /$ $\operatorname{EBP} \beta$ deficiency in adipogenesis [72]. VDR expression in
3T3-L1 cells inhabited PPAR $\gamma$ mRNA levels, which decreased adipogenesis [73]. These data indicated that VDR reduced adipogenesis through decreasing the expression of $\mathrm{C} / \mathrm{EBP} \beta$ and PPAR $\gamma$ and increasing ETO expression. The molecular mechanism of inhibitory effect of VDR on adipogenesis maybe due to the fact that RXR is a heterodimeric partner for both PPAR $\gamma$ and VDR, respectively, and that VDR leads to competition between RXR and PPAR $\gamma$ to decrease adipogenesis (Figure 2). Previous studies confirmed the competitive relationship between VDR and PPAR $\gamma$ for RXR [73-75]. Certainly, the mechanism underlying still needs to be proved by further investigation. Taken together, these investigations suggest that vitamin D plays a complex role through VDR and the transcription pathways in regulating adipogenesis.

3.2. Effect of Active Vitamin D on Adipogenesis. Adipogenesis is a cascade of differentiation that leads to adipocyte maturation. Adipocytes can affect many adipogenesis-related functions, such as adipokine secretion, lipid synthesis, fatty acid transfection, and insulin signaling response [76]. A vast amount of molecular interactions is involved during adipogenesis, and the main component is the expression of $\mathrm{C} / \mathrm{EBP} \beta$ and $\mathrm{PPAR} \gamma$ [77]. $\mathrm{C} / \mathrm{EBP} \beta$ and $\mathrm{C} / \mathrm{EBP} \delta$ are expressed in the early stage of adipogenesis. The adipogenesis is promoted under the regulation of $\mathrm{C} / \mathrm{EBP} \alpha, \beta$, and $\delta$ [78]. 1,25(OH)2D3 can inhibit 3T3-L1 preadipocyte 
differentiation by downregulating $\mathrm{C} / \mathrm{EBP} \beta$ and $\operatorname{PPAR} \gamma$ (Figure 2) [79, 80]. When combined with genistein, 1,25(OH) 2D3 inhibits adipocyte lipid-binding protein 2 expression and fat accumulation in 3T3-L1 preadipocytes [81].

VDR plays a vital role in adipogenesis. The activity of vitamin $\mathrm{D}$ is performed through 1,25(OH)2D3-VDR actions, and the target organs of VDR are the liver, kidney, genitourinary tract, intestine, bone, brain, and various immune cells $[5,82]$. VDR is expressed at the early stage of adipose differentiation [83]. Macrophage inflammation can induce the expression of VDR [84]. Knockdown of VDR in mice could lead to low-fat mass, high rates of $\beta$-oxidation, and adipogenesis inhibition; in $\mathrm{VDR}^{+/+}$cells, $1,25(\mathrm{OH}) 2 \mathrm{D} 3$ treatment can block adipogenesis $[72,83]$. In the absence of 1,25(OH)2D3, unliganded VDR also inhibits 3T3-L1 preadipocyte differentiation [73]. These data suggest a potential correlation between VDR and adipogenesis. In different phases of adipogenesis, 1,25(OH)2D3 could exert antiadipogenic activity through the $\mathrm{WNT} / \beta$-catenin pathway, the expression of mRNA modulation, and phosphorylation of extracellular regulated kinase via the mitogen-activated protein signaling pathway $[80,85]$.

Adiponectin is a hormone produced in adipose tissue and the brain. It is involved in the regulation of fatty acid oxidation [86, 87]. Adiponectin is abundant in plasma and is inversely related to body mass index [88]. Therefore, the biological effect of adiponectin can be related to serum concentration. Increased adiponectin in transgenic mice showed that the differentiation of 3T3-F442A cells is reduced through suppression of the expression of preadipocyte factor-1 mRNA and CCAAT enhancer-binding protein [89]. Adiponectin also plays a role in the suppression of metabolic disorders that may cause obesity, nonalcoholic fatty liver disease (NAFLD), or type-2 diabetes mellitus (T2DM) [87, 90, 91]. Moreover, administration of leptin and adiponectin can reverse insulin resistance in mice [92]. $1,25(\mathrm{OH}) 2 \mathrm{D} 3$ treatment can upregulate adiponectin in vitro and inhibit anti-inflammatory cytokine expression, and daily intake of fortified vitamin D can improve inflammation in T2DM $[88,93,94]$. However, data on the effect of $1,25(\mathrm{OH})_{2} \mathrm{D}_{3}$ on adiponectin in human adipocytes are lacking. Therefore, active vitamin $\mathrm{D}$ probably acts in adipogenesis by affecting insulin resistance, VDR, leptin expression, or inflammatory response [95-100].

\section{Vitamin D Deficiency with Lipid Metabolism Diseases}

4.1. Type-2 Diabetes. Diabetes mellitus (DM) is a consequence of metabolic disorders that contributes to the morbidity of obesity [101]. This disease has four types: type-1 DM (T1DM), type-2 DM (T2DM), gestational diabetes, and specific diabetes types with known causes [102]. T1DM, referred to as insulin-dependent DM, is caused by failure to produce enough insulin; T2DM is caused by the inability of the body to respond properly to insulin; gestational diabetes often occurs in pregnant women and could be overcome after pregnancy; and the fourth kind of DM is diabetes with known causes [102, 103]. About $90 \%$ of diabetes cases are
T2DM. Therefore, insulin resistance is a major factor for T2DM development. The morbidity of T2DM can be affected by environment, obesity, and age [104].

Low concentration of vitamin $\mathrm{D}$ is associated with T2DM patients. The serum concentration of $1,25(\mathrm{OH}) \mathrm{D}$ in $69.9 \%$ of 103 patients is lower than $20 \mathrm{ng} / \mathrm{ml}$ and negatively correlated with hemoglobin $\mathrm{A} 1 \mathrm{C}$ and insulin resistance [105]. In adults aged over 45 years, vitamin $\mathrm{D}$ deficiency is significantly associated with occurrence of T2DM [106]. Substantial evidence shows a link between vitamin $\mathrm{D}$ and T2DM [107].

Vitamin D deficiency can inhibit pancreatic insulin secretion; vitamin $\mathrm{D}$ can protect $\beta$-cells through cytokine regulation, promote depolarization by regulating the function of calcium-binding protein on pancreatic $\beta$-cells, and regulate the concentration of calcium ions and the flow of calcium through the cell membrane [108-111]. Therefore, the potential role of vitamin $\mathrm{D}$ is to induce the expression of insulin receptor, promote the expression of PPAR $\gamma$, or affect glucose transporter activity by regulating intracellular calcium levels [112-114].

Inflammation also participates in contributing insulin resistance. In T2DM patients, 1,25(OH)D can improve insulin resistance through negative regulation of the expression of inflammatory cytokines, such as interleukin-1, interleukin-6, interleukin-8, and tumor necrosis factor $\alpha$ [115]. Vitamin D deficiency can affect insulin secretion and resistance; thus, it plays a role in the occurrence and development of T2DM [116-118]. However, these meta-analyses still need to be improved because of the limited concentration used in the study (at least $2000 \mathrm{IU} /$ day) and the short investigation period on the patients.

4.2. Nonalcoholic Fatty Liver Disease. NAFLD is a stressinduced liver injury that is associated with insulin resistance and metabolic syndrome [119]. The causes of NAFLD are diabetes, obesity, age, and diet [120]. NAFLD has two types, namely, nonalcoholic fatty liver and nonalcoholic steatohepatitis [121, 122]. This disease is usually treated through weight loss and exercise. NAFLD is the most common chronic liver disorder in western countries [123]. It is a continuous process of liver injury, which may lead to steatohepatitis, cirrhosis, and liver cancer [124]. Vitamin D plays an important role in NAFLD development [125]. About 75\% of 5847 insulin resistance and metabolic syndrome patients have vitamin D deficiency [126]. The serum concentration of $1,25(\mathrm{OH}) \mathrm{D}$ is lower in patients with NAFLD than in normal patients, and the fatty liver index is negatively correlated with $1,25(\mathrm{OH}) \mathrm{D}$ level [127]. Treatment with vitamin D can improve insulin resistance in patients with glucose intolerance [128]. In vivo studies found that vitamin D deficiency and VDR knockdown reduce the secretion of insulin from pancreatic $\beta$-cells [129]. These results support that low levels of serum $25(\mathrm{OH}) \mathrm{D}$ are related to NAFLD.

Vitamin D is associated with insulin resistance phenotypic markers, such as HOMA-IR, ISI, adiponectin, triglyceride, and high-density lipoprotein cholesterol $[130,131]$. A prospective study on 524 nondiabetic patients 
aged 40-69 years has reported that serum 25(OH)D level is negatively correlated with blood glucose level and insulin resistance level [132]. The decrease in insulin sensitivity, pancreatic $\beta$-cell function, and insulin synthesis and secretion caused by low vitamin $\mathrm{D}$ level is related to insulin resistance. Vitamin D deficiency can promote the progress of impaired glucose tolerance, increase the expression of renin angiotensin system components, and damage the transcriptional function of pancreatic genes [133]. Vitamin D also decreases insulin resistance by downregulating the expression of PPAR $\gamma 2$, suppressing the differentiation of 3T3-L1 preadipocytes, and inhibiting adipogenesis [134]. Studies in vivo and in vitro showed that vitamin $\mathrm{D}$ is related to the pathogenesis and progress of NAFLD.

4.3. Cardiovascular Risk. Previous study indicated that endothelial dysfunction represents an early event in cardiovascular diseases, and there is an association between vitamin $\mathrm{D}$ levels and endothelial dysfunction. In addition, vitamin $\mathrm{D}$ levels negatively correlated with flow-mediated dilatation (FMD) in many patients affected by type 2 diabetes, whereas current data are still insufficient to confirm vitamin $\mathrm{D}$ deficiency or insufficiency lead to an increased cardiovascular risk [135]. The relationship between vitamin D deficiency and cardiovascular risk, as well as mechanism underlying also still needs to be proved by further investigation.

\section{Conclusions}

This review was dedicated to reveal the correlation between vitamin $\mathrm{D}$ and adipogenesis, with emphasis on the diseases related to adipose metabolic disorders. Vitamin D has several influences on adipogenesis. Active vitamin D is mainly produced, stored, and degraded in adipose tissue, and VDR is expressed in adipose tissue. Vitamin D affects adipogenesis by regulating the expression of adipocyte transcription factors, such as PPAR $\gamma, \mathrm{C} / \mathrm{EBP} \alpha$, and LPL, and through affecting insulin resistance, VDR and unliganded VDR, and adipokine secretion.

Adipose metabolic disorders, such as obesity, diabetes, and NAFLD, were specifically chosen in this review. Obesity is a common occurrence worldwide, and it can lead to diabetes and NAFLD. Many studies have indicated that vitamin D deficiency or insufficiency plays an important role in the development and process of obesity, diabetes, and NAFLD. Aside from the diseases discussed in the review, other diseases are also associated with vitamin deficiency, such as hyperlipidemia, ketosis, ketonuria, and atherosclerosis. However, the effect of vitamin $\mathrm{D}$ on adipogenesis in lean individuals and the function of calcium in adipogenesis are still keeping elusive. Vitamin D supplements are a promising way to alleviate the burden caused by these diseases. In conclusion, vitamin $\mathrm{D}$ administration can provide a new basis for medical therapy.

\section{Conflicts of Interest}

We declare that we have no conflicts of interest.

\section{Authors' Contributions}

All authors participated in the search, writing, and revising of the manuscript. Zhiguo Miao and Shan Wang contributed equally to this work.

\section{Acknowledgments}

This study was supported by the grants from the Henan Joint Funds of National Natural Science Foundation of China (U1604102).

\section{References}

[1] C. Quinn, "Vitamin D: the sunshine vitamin," British Journal of Nursing, vol. 19, no. 18, pp. 11160-11163, 2010.

[2] M. F. Holick, "Resurrection of vitamin D deficiency and rickets," Journal of Clinical Investigation, vol. 116, no. 8, pp. 2062-2072, 2006.

[3] A. S. Dusso, A. J. Brown, and E. Slatopolsky, "Vitamin D," American Journal of Physiology-Renal Physiology, vol. 289, no. 1, pp. F8-F28, 2005.

[4] K. D. Cashman, E. G. H. M. van den Heuvel, R. J. W. Schoemaker, D. P. Prévéraud, H. M. Macdonald, and J. Arcot, "25-Hydroxyvitamin D as a biomarker of vitamin D status and its modeling to inform strategies for prevention of vitamin $\mathrm{D}$ deficiency within the population," Advances in Nutrition: An International Review Journal, vol. 8, no. 6, pp. 947-957, 2017.

[5] D. D. Bikle, "Vitamin D metabolism, mechanism of action, and clinical applications," Chemistry \& Biology, vol. 21, no. 3, pp. 319-329, 2014.

[6] S. Fukumoto, "Phosphate metabolism and vitamin D," BoneKEy Reports, vol. 3, 2014.

[7] G. Jones, D. E. Prosser, and M. Kaufmann, "Cytochrome P450-mediated metabolism of vitamin D," Journal of Lipid Research, vol. 55, no. 1, pp. 13-31, 2014.

[8] M. F. Holick and T. C. Chen, "Vitamin D deficiency: a worldwide problem with health consequences," The American Journal of Clinical Nutrition, vol. 87, no. 4, pp. 1080S1086S, 2008.

[9] D. E. Roth, S. A. Abrams, J. Aloia et al., "Global prevalence and disease burden of vitamin D deficiency: a roadmap for action in low- and middle-income countries," Annals of the New York Academy of Sciences, vol. 1430, no. 1, pp. 44-79, 2018.

[10] J.-S. Kim, "Factors associated with vitamin D status among Korean female adolescents," Journal of Pediatric Nursing, vol. 44, pp. e79-e83, 2019.

[11] B. Prietl, G. Treiber, T. Pieber, and K. Amrein, "Vitamin D and immune function," Nutrients, vol. 5, no. 7, pp. 25022521, 2013.

[12] S. Christakos, M. Hewison, D. G. Gardner et al., "Vitamin D: beyond bone," Annals of the New York Academy of Science, vol. 1287, no. 1, pp. 45-58, 2013.

[13] S. Samuel and M. D. Sitrin, "Vitamin D's role in cell proliferation and differentiation," Nutrition Reviews, vol. 66, no. 10 Suppl 2, pp. S116-S124, 2008.

[14] K. A. Virtanen, M. E. Lidell, J. Orava et al., "Functional brown adipose tissue in healthy adults," New England Journal of Medicine, vol. 360, no. 15, pp. 1518-1525, 2009.

[15] A. I. Li, A. Hokugo, R. Jarrahy, and P. A. Zuk, "Human adipose tissue as a source of multipotent stem cells," in Stem 
Cells In Aesthetic Procedures, pp. 67-83, Springer, Berlin, Germany, 2014.

[16] A. Bartelt and J. Heeren, "Adipose tissue browning and metabolic health," Nature Reviews Endocrinology, vol. 10, no. 1, pp. 24-36, 2014.

[17] M. Coelho, T. Oliveira, and R. Fernandes, "State of the art paper Biochemistry of adipose tissue: an endocrine organ," Archives of Medical Science, vol. 2, no. 2, pp. 191-200, 2013.

[18] M. E. F. Vázquez-Vela, N. Torres, and A. R. Tovar, "White adipose tissue as endocrine organ and its role in obesity," Archives of Medical Research, vol. 39, no. 8, pp. 715-728, 2008.

[19] F. M. Gregoire, C. M. Smas, and H. S. Sul, "Understanding adipocyte differentiation," Physiological Reviews, vol. 78, no. 3, pp. 783-809, 1998.

[20] T. Suganami and Y. Ogawa, "Adipose tissue macrophages: their role in adipose tissue remodeling," Journal of Leukocyte Biology, vol. 88, no. 1, pp. 33-39, 2010.

[21] J. Marcotorchino, F. Tourniaire, and J. F. Landrier, "Vitamin D, adipose tissue, and obesity," Hormone Molecular Biology and Clinical Investigation, vol. 15, no. 3, pp. 123-128, 2013.

[22] Z. Cerit, "Vitamin D, body composition, and epicardial adipose tissue," Clinical Nutrition, vol. 36, no. 5, p. 1450, 2017.

[23] I. N. Sergeev and Q. Song, "High vitamin D and calcium intakes reduce diet-induced obesity in mice by increasing adipose tissue apoptosis," Molecular Nutrition \& Food Research, vol. 58, no. 6, pp. 1342-1348, 2014.

[24] K. E. Wong, J. Kong, W. Zhang et al., "Targeted expression of human vitamin D receptor in adipocytes decreases energy expenditure and induces obesity in mice," Journal of Biological Chemistry, vol. 286, no. 39, pp. 33804-33810, 2011.

[25] Y. Hida, T. Kawada, S. Kayahashi, T. Ishihara, and T. Fushiki, "Counteraction of retinoic acid and 1,25-dihydroxyvitamin D3 on up-regulation of adipocyte differentiation with PPARgamma ligand, an antidiabetic thiazolidinedione, in 3T3-L1 cells," Life Sciences, vol. 62, no. 14, pp. PL205-PL211, 1998.

[26] P. Manna, A. E. Achari, and S. K. Jain, "Vitamin D supplementation inhibits oxidative stress and upregulate SIRT1/ AMPK/GLUT4 cascade in high glucose-treated 3T3L1 adipocytes and in adipose tissue of high fat diet-fed diabetic mice," Archives of Biochemistry and Biophysics, vol. 615, pp. 22-34, 2017.

[27] B. M. Larrick, K.-H. Kim, S. S. Donkin, and D. Teegarden, "1,25-dihydroxyvitamin D regulates lipid metabolism and glucose utilization in differentiated 3T3-L1 adipocytes," Nutrition Research, vol. 58, pp. 72-83, 2018.

[28] G. K. Gupta, T. Agrawal, M. G. DelCore, S. M. Mohiuddin, and D. K. Agrawal, "Vitamin D deficiency induces cardiac hypertrophy and inflammation in epicardial adipose tissue in hypercholesterolemic swine," Experimental and Molecular Pathology, vol. 93, no. 1, pp. 82-90, 2012.

[29] C. Cipriani, J. Pepe, S. Piemonte, L. Colangelo, M. Cilli, and S. Minisola, "Vitamin d and its relationship with obesity and muscle," International Journal of Endocrinology, vol. 2014, Article ID 841248, 11 pages, 2014.

[30] X. Chen, W. Wu, L. Wang et al., "Association between 25hydroxyvitamin D and epicardial adipose tissue in Chinese non-obese patients with type 2 diabetes," Medical Science Monitor, vol. 23, pp. 4304-4311, 2017.

[31] I. K. Utku, "Relationship between epicardial adipose tissue thickness and vitamin D in patients with metabolic syndrome," International Journal of Clinical and Experimental Medicine, vol. 8, no. 4, pp. 5707-5714, 2015.
[32] E. Papakonstantinou, W. P. Flatt, P. J. Huth, and R. B. S. Harris, "High dietary calcium reduces body fat content, digestibility of fat, and serum vitamin D in rats," Obesity Research, vol. 11, no. 3, pp. 387-394, 2003.

[33] R. Vieth, H. Bischoff-Ferrari, B. J. Boucher et al., "The urgent need to recommend an intake of vitamin D that is effective," The American Journal of Clinical Nutrition, vol. 85, no. 3, pp. 649-650, 2007.

[34] M. Wacker and M. F. Holick, "Sunlight and vitamin D," Dermato-Endocrinology, vol. 5, no. 1, pp. 51-108, 2013.

[35] M. F. Holick, "Ultraviolet B radiation: the vitamin D connection," Advances in Experimental Medicine and Biology, vol. 996, pp. 137-154, 2017.

[36] A. S. Heravi and E. D. Michos, "Vitamin D and calcium supplements: helpful, harmful, or neutral for cardiovascular risk?” Methodist DeBakey Cardiovascular Journal, vol. 15, no. 3, pp. 207-213, 2019.

[37] J. E. Zerwekh, "Blood biomarkers of vitamin D status," The American Journal of Clinical Nutrition, vol. 87, no. 4, pp. 1087S-1091S, 2008.

[38] B. W. Hollis, "Assessment of vitamin D nutritional and hormonal status: what to measure and how to do it," Calcified Tissue International, vol. 58, no. 1, pp. 4-5, 1996.

[39] M. Cantorna, L. Snyder, Y.-D. Lin, and L. Yang, "Vitamin D and $1,25(\mathrm{OH}) 2 \mathrm{D}$ regulation of T cells," Nutrients, vol. 7, no. 4, pp. 3011-3021, 2015.

[40] D. Saccone, F. Asani, and L. Bornman, "Regulation of the vitamin $\mathrm{D}$ receptor gene by environment, genetics and epigenetics," Gene, vol. 561, no. 2, pp. 171-180, 2015.

[41] S. Kato, "The function of vitamin D receptor in vitamin D action," Journal of Biochemistry, vol. 127, no. 5, pp. 717-722, 2000.

[42] A. G. Uitterlinden, Y. Fang, J. B. J. Van Meurs, H. A. P. Pols, and J. P. T. M. Van Leeuwen, "Genetics and biology of vitamin D receptor polymorphisms," Gene, vol. 338, no. 2, pp. 143-156, 2004.

[43] T. S. Lisse, R. F. Chun, S. Rieger, J. S. Adams, and M. Hewison, "Vitamin D activation of functionally distinct regulatory miRNAs in primary human osteoblasts," Journal of Bone and Mineral Research, vol. 28, no. 6, pp. 1478-1488, 2013.

[44] O. Sahota, "Understanding vitamin D deficiency," Age and Ageing, vol. 43, no. 5, pp. 589-591, 2014.

[45] L. Adorini, K. Daniel, and G. Penna, "Vitamin D receptor agonists, cancer and the immune system: an intricate relationship," Current Topics in Medicinal Chemistry, vol. 6, no. 12, pp. 1297-1301, 2006.

[46] J. M. Valdivielso and E. Fernandez, "Vitamin D receptor polymorphisms and diseases," Clinica Chimica Acta, vol. 371, no. 1-2, pp. 1-12, 2006.

[47] M. C. Silva and T. W. Furlanetto, "Intestinal absorption of vitamin D: a systematic review," Nutrition Reviews, vol. 76, no. 1, pp. 60-76, 2018.

[48] E. Reboul, "Intestinal absorption of vitamin D: from the meal to the enterocyte," Food \& Function, vol. 6, no. 2, pp. 356-362, 2015.

[49] K. Wikvall, "Cytochrome P450 enzymes in the bioactivation of vitamin D to its hormonal form (review)," International Journal of Molecular Medicine, vol. 7, no. 2, pp. 201-209, 2001.

[50] G. Jones, "Pharmacokinetics of vitamin D toxicity," The American Journal of Clinical Nutrition, vol. 88, no. 2, pp. 582S-586S, 2008. 
[51] S.-i. Hayashi, E. Usui, and K. Okuda, "Sex-related difference in vitamin D3 25-hydroxylase of rat liver microsomes," The Journal of Biochemistry, vol. 103, no. 5, pp. 863-866, 1988.

[52] K. Saarem, S. Bergseth, H. Oftebro, and J. I. Pedersen, "Subcellular localization of vitamin D3 25-hydroxylase in human liver," Journal of Biological Chemistry, vol. 259, no. 17, pp. 10936-10940, 1984.

[53] L. Wamberg, T. Christiansen, S. K. Paulsen et al., "Expression of vitamin $\mathrm{D}$-metabolizing enzymes in human adipose tissue-the effect of obesity and diet-induced weight loss," International Journal of Obesity, vol. 37, no. 5, pp. 651-657, 2013.

[54] J. S. Adams and M. Hewison, "Update in vitamin D," The Journal of Clinical Endocrinology \& Metabolism, vol. 95, no. 2, pp. 471-478, 2010.

[55] M. Holick, J. MacLaughlin, M. Clark et al., "Photosynthesis of previtamin D3 in human skin and the physiologic consequences," Science, vol. 210, no. 4466, pp. 203-205, 1980.

[56] A. Carrelli, M. Bucovsky, R. Horst et al., "Vitamin D storage in adipose tissue of obese and normal weight women," Journal of Bone and Mineral Research, vol. 32, no. 2, pp. 237-242, 2017.

[57] E. B. Mawer, J. Backhouse, C. A. Holman, G. A. Lumb, and S. W. Stanbury, "The distribution and storage of vitamin D and its metabolites in human tissues," Clinical Science, vol. 43, no. 3, pp. 413-431, 1972.

[58] S. J. Mutt, E. Hyppönen, J. Saarnio, M.-R. Järvelin, and K.-H. Herzig, "Vitamin D and adipose tissue-more than storage," Fronters in Physiology, vol. 5, p. 228, 2014.

[59] F. Sassi, C. Tamone, and P. D'amelio, "Vitamin D: nutrient, hormone, and immunomodulator," Nutrients, vol. 10, no. 11, p. 1656, 2018.

[60] J. Sun, "Dietary vitamin D, vitamin D receptor, and microbiome," Current Opinion in Clinical Nutrition and Metabolic Care, vol. 21, no. 6, pp. 471-474, 2018.

[61] W. Liu, L. Zhang, H.-J. Xu et al., "The anti-inflammatory effects of vitamin D in tumorigenesis," International Journal of Molecular Sciences, vol. 19, no. 9, p. 2736, 2018.

[62] R. A. G. Khammissa, J. Fourie, M. H. Motswaledi, R. Ballyram, J. Lemmer, and R. L. Feller, "The biological activities of vitamin $\mathrm{D}$ and its receptor in relation to calcium and bone homeostasis, cancer, immune and cardiovascular systems, skin biology, and oral health," BioMed Research Internatioonal, vol. 2018, Article ID 9276380, 9 pages, 2018.

[63] M. Umar, K. S. Sastry, and A. I. Chouchane, "Role of vitamin $D$ beyond the skeletal function: a review of the molecular and clinical studies," International Journal of Molecular Sciences, vol. 19, no. 6, p. 1618, 2018.

[64] H. F. DeLuca, "Overview of general physiologic features and functions of vitamin D," The American Journal of Clinical Nutrition, vol. 80, no. 6 Suppl, pp. 1689S-1696S, 2004.

[65] J. Li, M. E. Byrne, E. Chang et al., " $1 \alpha$, 25-dihydroxyvitamin D hydroxylase in adipocytes," The Journal of Steroid Biochemistry and Molecular Biology, vol. 112, no. 1-3, pp. 122-126, 2008.

[66] A. Pramono, J. W. E. Jocken, Y. P. G. Essers, G. H. Goossens, and E. E. Blaak, "Vitamin D and tissue-specific insulin sensitivity in humans with overweight/obesity," The Journal of Clinical Endocrinology \& Metabolism, vol. 104, no. 1, pp. 49-56, 2019.

[67] M. Pelczyńska, T. Grzelak, M. Walczak, and K. Czyżewska, "Hypovitaminosis D and adipose tissue - cause and effect relationships in obesity," Annals of Agricutural and Environmental Medicine, vol. 23, no. 3, pp. 403-409, 2016.
[68] X.-M. Mai, Y. Chen, C. A. Camargo, and A. Langhammer, "Cross-sectional and prospective cohort study of serum 25hydroxyvitamin D level and obesity in adults: the HUNT study," American Journal of Epidemiology, vol. 175, no. 10, pp. 1029-1036, 2012.

[69] M. F. Holick, N. C. Binkley, H. A. Bischoff-Ferrari et al., "Evaluation, treatment, and prevention of vitamin D deficiency: an endocrine society clinical practice guideline," The Journal of Clinical Endocrinology \& Metabolism, vol. 96, no. 7, pp. 1911-1930, 2011.

[70] M. Blum, G. Dolnikowski, E. Seyoum et al., "Vitamin D3 in fat tissue," Endocrine, vol. 33, no. 1, pp. 90-94, 2008.

[71] A. T. Drincic, L. A. G. Armas, E. E. Van Diest, and R. P. Heaney, "Volumetric dilution, rather than sequestration best explains the low vitamin D status of obesity," Obesity, vol. 20, no. 7, pp. 1444-1448, 2012.

[72] J. M. Blumberg, I. Tzameli, I. Astapova, F. S. Lam, J. S. Flier, and A. N. Hollenberg, "Complex role of the vitamin D receptor and its ligand in adipogenesis in 3T3-L1 cells," Journal of Biological Chemistry, vol. 281, no. 16, pp. 11205-11213, 2006.

[73] J. Kong and Y. C. Li, "Molecular mechanism of 1,25-dihydroxyvitamin D3 inhibition of adipogenesis in 3T3-L1 cells," American Journal of Physiology-Endocrinology and Metabolism, vol. 290, no. 5, pp. E916-E924, 2006.

[74] B. Wang, Q. Yang, C. L. Harris et al., "Nutrigenomic regulation of adipose tissue development - role of retinoic acid: a review," Meat Science, vol. 120, pp. 100-106, 2016.

[75] S. Ji, M. E. Doumit, and R. A. Hill, "Regulation of adipogenesis and key adipogenic gene expression by 1,25-dihydroxyvitamin D in 3T3-L1 cells," PLoS One, vol. 10, no. 6, Article ID e126142, 2015.

[76] A. M. Komai, C. Brännmark, S. Musovic, and C. S. Olofsson, "PKA-independent cAMP stimulation of white adipocyte exocytosis and adipokine secretion: modulations by $\mathrm{Ca} 2+$ and ATP," The Journal of Physiology, vol. 592, no. 23, pp. 5169-5186, 2014.

[77] R. J. Wood, "Vitamin D and adipogenesis: new molecular insights," Nutrition Reviews, vol. 66, no. 1, pp. 40-46, 2008.

[78] E. D. Rosen, "C/EBPalpha induces adipogenesis through PPARgamma: a unified pathway," Genes \& Development, vol. 16, no. 1, pp. 22-26, 2002.

[79] P. M. de Sá, A. J. Richard, H. Hang, and J. M. Stephens, "Transcriptional regulation of adipogenesis," Comprehensive Physiology, vol. 7, no. 2, pp. 635-674, 2017.

[80] S. Sakuma, J. Fujisawa, M. Sumida et al., "The involvement of mitogen-activated protein kinases in the $1 \alpha, 25$-dihydroxycholecalciferol-induced inhibition of adipocyte differentiation in vitro," Journal of Nutritional Science and Vitaminology, vol. 58, no. 1, pp. 1-8, 2012.

[81] S. Rayalam, M. Anne Della-Fera, S. Ambati, J.-Y. Yang, H. Jin Park, and C. A. Baile, "Enhanced effects of 1,25(OH)(2)D(3) plus genistein on adipogenesis and apoptosis in 3T3-L1 adipocytes," Obesity, vol. 16, no. 3, pp. 539-546, 2008.

[82] S. Christakos, P. Dhawan, A. Verstuyf, L. Verlinden, and G. Carmeliet, "Vitamin D: metabolism, molecular mechanism of action, and pleiotropic effects," Physiological Reviews, vol. 96, no. 1, pp. 365-408, 2016.

[83] K. E. Wong, F. L. Szeto, W. Zhang et al., "Involvement of the vitamin D receptor in energy metabolism: regulation of uncoupling proteins," American Journal of Physiology-Endocrinology and Metabolism, vol. 296, no. 4, pp. E820-E828, 2009. 
[84] A. O’Hara, F. L. Lim, D. J. Mazzatti, and P. Trayhurn, "Microarray analysis identifies matrix metalloproteinases (MMPs) as key genes whose expression is up-regulated in human adipocytes by macrophage-conditioned medium," Pflügers Archiv: European Journal of Physiology, vol. 458, no. 6, pp. 1103-1114, 2009.

[85] H. Lee, S. Bae, and Y. Yoon, "Anti-adipogenic effects of 1,25dihydroxyvitamin D3 are mediated by the maintenance of the wingless-type MMTV integration site/ $\beta$-catenin pathway," International Journal of Molecular Medicine, vol. 30, no. 5, pp. 1219-1224, 2012.

[86] K. Maeda, K. Okubo, I. Shimomura, T. Funahashi, Y. Matsuzawa, and K. Matsubara, "cDNA cloning and expression of a novel adipose specific collagen-like factor, apM1 (ADIPOSE most ABUNDANT gene transcript 1)," Biochemical and Biophysical Research Communications, vol. 221, no. 2, pp. 286-289, 1996.

[87] J. Diez and P. Iglesias, "The role of the novel adipocytederived hormone adiponectin in human disease," European Journal of Endocrinology, vol. 148, no. 3, pp. 293-300, 2003.

[88] M. Smotkin-Tangorra, R. Purushothaman, A. Gupta, G. Nejati, H. Anhalt, and S. Ten, "Prevalence of vitamin D insufficiency in obese children and adolescents," Journal of Pediatric Endocrinology and Metabolism, vol. 20, no. 7, pp. 817-823, 2007.

[89] I. B. Bauche, S. A. El Mkadem, A.-M. Pottier et al., "Overexpression of adiponectin targeted to adipose tissue in transgenic mice: impaired adipocyte differentiation," Endocrinology, vol. 148, no. 4, pp. 1539-1549, 2007.

[90] O. Ukkola and M. Santaniemi, "Adiponectin: a link between excess adiposity and associated comorbidities?," Journal of Molecular Medicine, vol. 80, no. 11, pp. 696-702, 2002.

[91] K. E. Peters, W. A. Davis, J. Beilby, J. Hung, D. G. Bruce, and T. M. E. Davis, "The relationship between circulating adiponectin, ADIPOQ variants and incident cardiovascular disease in type 2 diabetes: the fremantle diabetes study," Diabetes Research and Clinical Practice, vol. 143, pp. 62-70, 2018.

[92] T. Yamauchi, J. Kamon, H. Waki et al., "The fat-derived hormone adiponectin reverses insulin resistance associated with both lipoatrophy and obesity," Nature Medicine, vol. 7, no. 8, pp. 941-946, 2001.

[93] X. Sun and M. B. Zemel, "Calcium and 1,25-dihydroxyvitamin D3 regulation of adipokine expression," Obesity, vol. 15, no. 2, pp. 340-348, 2007.

[94] T. R. Neyestani, B. Nikooyeh, H. Alavi-Majd et al., "Improvement of vitamin D status via daily intake of fortified yogurt drink either with or without extra calcium ameliorates systemic inflammatory biomarkers, including adipokines, in the subjects with type 2 diabetes," The Journal of Clinical Endocrinology \& Metabolism, vol. 97, no. 6, pp. 2005-2011, 2012.

[95] K. C. Chiu, A. Chu, V. L. W. Go, and M. F. Saad, "Hypovitaminosis $\mathrm{D}$ is associated with insulin resistance and beta cell dysfunction," The American Journal of Clinical Nutrition, vol. 79, no. 5, pp. 820-825, 2004.

[96] S. J. Wimalawansa, "Associations of vitamin D with insulin resistance, obesity, type 2 diabetes, and metabolic syndrome," The Journal of Steroid Biochemistry and Molecular Biology, vol. 175, pp. 177-189, 2018.

[97] D. Bikle, "Nonclassic actions of vitamin D," The Journal of Clinical Endocrinology \& Metabolism, vol. 94, no. 1, pp. 26-34, 2009.
[98] M. D. Klok, S. Jakobsdottir, and M. L. Drent, "The role of leptin and ghrelin in the regulation of food intake and body weight in humans: a review," Obesity Reviews, vol. 8, no. 1, pp. 21-34, 2007.

[99] C. E. A. Chagas, M. C. Borges, L. A. Martini, and M. M. Rogero, "Focus on vitamin D, inflammation and type 2 diabetes," Nutrients, vol. 4, no. 1, pp. 52-67, 2012.

[100] J. L. Nobre, P. C. Lisboa, J. C. Carvalho et al., "Leptin blocks the inhibitory effect of vitamin D on adipogenesis and cell proliferation in 3T3-L1 adipocytes," General and Comparative Endocrinology, vol. 266, pp. 1-8, 2018.

[101] A. Karaa and A. Goldstein, "The spectrum of clinical presentation, diagnosis, and management of mitochondrial forms of diabetes," Pediatric Diabetes, vol. 16, no. 1, pp. 1-9, 2015.

[102] A. Petersmann, M. Nauck, D. Müller-Wieland et al., "Definition, classification and diagnostics of diabetes mellitus," LaboratoriumsMedizin, vol. 42, no. 3, pp. 73-79, 2018.

[103] M. Roden, "Diabetes mellitus-definition, klassifikation und diagnose," Wiener Klinische Wochenschrift, vol. 124, no. S2, pp. 1-3, 2012.

[104] S. Canivell and R. Gomis, "Diagnosis and classification of autoimmune diabetes mellitus," Autoimmunity Reviews, vol. 13, no. 4-5, pp. 403-407, 2014.

[105] J. M. Calvo-Romero and J. M. Ramiro-Lozano, "Vitamin D levels in patients with type 2 diabetes mellitus," Journal of Investigative Medicine, vol. 63, no. 8, pp. 921-923, 2015.

[106] D. Mauss, M. N. Jarczok, K. Hoffmann, G. N. Thomas, and J. E. Fischer, "Association of vitamin D levels with type 2 diabetes in older working adults," International Journal of Medical Sciences, vol. 12, no. 5, pp. 362-368, 2015.

[107] S. Afzal, S. E. Bojesen, and B. G. Nordestgaard, "Low 25hydroxyvitamin $\mathrm{D}$ and risk of type 2 diabetes: a prospective cohort study and metaanalysis," Clinical Chemistry, vol. 59, no. 2, pp. 381-391, 2013.

[108] S. A. Clark, W. E. Stumpf, and M. Sar, "Effect of 1,25 dihydroxyvitamin D3 on insulin secretion," Diabetes, vol. 30, no. 5, pp. 382-386, 1981.

[109] S. Kadowaki and A. W. Norman, "Pancreatic vitamin D-dependent calcium binding protein: biochemical properties and response to vitamin D," Archives of Biochemistry and Biophysics, vol. 233, no. 1, pp. 228-236, 1984.

[110] H. Wolden-Kirk, L. Overbergh, H. T. Christesen, K. Brusgaard, and C. Mathieu, "Vitamin D and diabetes: its importance for beta cell and immune function," Molecular and Cellular Endocrinology, vol. 347, no. 1-2, pp. 106-120, 2011.

[111] A. Norman, J. Frankel, A. Heldt, and G. Grodsky, "Vitamin D deficiency inhibits pancreatic secretion of insulin," Science, vol. 209, no. 4458, pp. 823-825, 1980.

[112] B. Maestro, S. Molero, S. Bajo, N. Dávila, and C. Calle, "Transcriptional activation of the human insulin receptor gene by 1,25-dihydroxyvitamin $\mathrm{D}(3)$," Cell Biochemistry and Function, vol. 20, no. 3, pp. 227-232, 2002.

[113] B. Maestro, N. Dávila, M. C. Carranza, and C. Calle, "Identification of a Vitamin D response element in the human insulin receptor gene promoter," The Journal of Steroid Biochemistry and Molecular Biology, vol. 84, no. 2-3, pp. 223-230, 2003.

[114] M. B. Zemel, "Nutritional and endocrine modulation of intracellular calcium: implications in obesity, insulin resistance and hypertension," in Molecular and Cellular Effects of Nutrition on Disease Processes, pp. 129-136, Springer, Berlin, Germany, 1998. 
[115] A. Giulietti, E. van Etten, L. Overbergh, K. Stoffels, R. Bouillon, and C. Mathieu, "Monocytes from type 2 diabetic patients have a pro-inflammatory profile. 1,25-Dihydroxyvitamin $\mathrm{D}(3)$ works as anti-inflammatory," Diabetes Research and Clinical Practice, vol. 77, no. 1, pp. 47-57, 2007.

[116] B. Garcia-Bailo, "Vitamins D, C, and E in the prevention of type 2 diabetes mellitus: modulation of inflammation and oxidative stress," Biologics: Targets and Therapy, vol. 5, pp. 7-19, 2011.

[117] G. Bjelakovic, L. L. Gluud, D. Nikolova et al., "Vitamin D supplementation for prevention of mortality in adults," Cochrane Database of Systematic Reviews, vol. 10, no. 1, 2014.

[118] P. S. Leung, “The potential protective action of vitamin D in hepatic insulin resistance and pancreatic islet dysfunction in type 2 diabetes mellitus," Nutrients, vol. 8, no. 3, p. 147, 2016.

[119] K. Atay, "Apoptosis and disease severity is associated with insulin resistance in non-alcoholic fatty liver disease," Acta Gastro-Enterologica Belgica, vol. 80, no. 2, pp. 271-277, 2017.

[120] P. Bedossa, "Pathology of non-alcoholic fatty liver disease," Liver International, vol. 37, no. Suppl 1, pp. 85-89, 2017.

[121] N. Chalasani, Z. Younossi, J. E. Lavine et al., "The diagnosis and management of nonalcoholic fatty liver disease: practice guidance from the American association for the study of liver diseases," Hepatology, vol. 67, no. 1, pp. 328-357, 2018.

[122] D. Iser and M. Ryan, "Fatty liver disease-a practical guide for GPs," Australian Family Physician, vol. 42, no. 7, pp. 444-447, 2013.

[123] Z. M. Younossi, A. B. Koenig, D. Abdelatif, Y. Fazel, L. Henry, and M. Wymer, "Global epidemiology of nonalcoholic fatty liver disease-meta-analytic assessment of prevalence, incidence, and outcomes," Hepatology, vol. 64, no. 1, pp. 73-84, 2016.

[124] M. E. Rinella and A. J. Sanyal, "Management of NAFLD: a stage-based approach," Nature Reviews Gastroenterology \& Hepatology, vol. 13, no. 4, pp. 196-205, 2016.

[125] M. Eliades and E. Spyrou, "Vitamin D: a new player in nonalcoholic fatty liver disease?" World Journal of Gastroenterology, vol. 21, no. 6, pp. 1718-1727, 2015.

[126] N. R. Pinelli, L. A. Jaber, M. B. Brown, and W. H. Herman, "Serum 25-hydroxy vitamin $\mathrm{d}$ and insulin resistance, metabolic syndrome, and glucose intolerance among Arab Americans," Diabetes Care, vol. 33, no. 6, pp. 1373-1375, 2010.

[127] I. Barchetta, F. Angelico, M. D. Ben et al., "Strong association between non alcoholic fatty liver disease (NAFLD) and low $25(\mathrm{OH})$ vitamin D levels in an adult population with normal serum liver enzymes," BMC Medicine, vol. 9, no. 1, p. 85, 2011.

[128] J. Mitri, M. D. Muraru, and A. G. Pittas, "Vitamin D and type 2 diabetes: a systematic review," European Journal of Clinical Nutrition, vol. 65, no. 9, pp. 1005-1015, 2011.

[129] O. Andrukhova, S. Slavic, U. Zeitz et al., "Vitamin D is a regulator of endothelial nitric oxide synthase and arterial stiffness in mice," Molecular Endocrinology, vol. 28, no. 1, pp. 53-64, 2014.

[130] C. F. Dix, J. L. Barclay, and O. R. L. Wright, "The role of vitamin D in adipogenesis," Nutrition Reviews, vol. 76, no. 1, pp. 47-59, 2018.

[131] C.-C. Sung, M.-T. Liao, K.-C. Lu, and C.-C. Wu, "Role of vitamin D in insulin resistance," Journal of Biomedicine and Biotechnology, vol. 2012, Article ID 634195, 11 pages, 2012.

[132] N. G. Forouhi, J. Luan, A. Cooper, B. J. Boucher, and N. J. Wareham, "Baseline serum 25-hydroxy vitamin $\mathrm{d}$ is predictive of future glycemic status and insulin resistance: the medical research council ely prospective study 1990-2000," Diabetes, vol. 57, no. 10, pp. 2619-2625, 2008.

[133] Q. Cheng, B. J. Boucher, and P. S. Leung, "Modulation of hypovitaminosis D-induced islet dysfunction and insulin resistance through direct suppression of the pancreatic islet renin-angiotensin system in mice," Diabetologia, vol. 56, no. 3, pp. 553-562, 2013.

[134] S. Lee, D.-K. Lee, E. Choi, and J. W. Lee, "Identification of a functional vitamin D response element in the murine insig-2 promoter and its potential role in the differentiation of 3T3L1 preadipocytes," Molecular Endocrinology, vol. 19, no. 2, pp. 399-408, 2005.

[135] M. Caprio, C. Mammi, and G. M. C. Rosano, "Vitamin D: a novel player in endothelial function and dysfunction," Archives of Medical Science, vol. 1, no. 1, pp. 4-5, 2012. 